\title{
TO THE HISTORY OF EXPLORATION OF THE KUIALNYTSKYI (SOTNYKIVSKYI) CEMETERY IN ODESSA
}

\author{
Taras Goncharuk \\ DSc (History), Professor \\ Odessa I. I. Mechnikov National University \\ 2, Dvoryanska Str., Odessa, 65082, Ukraine \\ tarasiy2004@ukr.net
}

In the article was made an attempt to analyze the historiography of the studying of the cemetery of the Kuialnyk suburb, located in Odessa, which contain the tombstones (the crosses), similar to the Zaporozhian Cossack tombstones. Also the research includes the correct dating of the oldest signed tombstone oft he Cemetery (1791), that was at first documented by the scientist Roman Shuvalov. Author proposed the version that people buried in the Cemetery could be former Black Sea Cossacks and their descendants, who went to work to the quarry of Odesa. The scholar noted thatat the Cemetery were also buried the relatives of those stonemasons who had extracted the stones for the construction of the modern symbol of Odesa - the Potemkin Stairs.

Keywords: the Cossack cemeteries, the necropolis of Odessa, Odessa, Kulianik.

Тарас Гончарук

Доктор історичний наук, професор Одеський національний університет імені I. I. Мечникова Вум. Дворянська, 2, Одеса, 65082, Україна tarasiy2004@ukr.net

\section{ДО ІСТОРІЇ ВИВЧЕННЯ КУЯАЬНИЦЬКОГО (СОТНИКІВСЬКОГО) КААДОВИЩА М. ОДЕСИ}

До уваги читачів запропоновано інформаиію про історіографію вивчення кладовища передмістя Куяльник, шо розташоване в межах міста Одеси й містить надгробки (хрести) подібні до нагробків запорозьких козаків. В замітиі доводиться правильність датування найстаршого підписаного надгробку кладовища 1791 р., що свого часу стверджував дослідник Роман Шувалов. Висувається версія, що поховані на кладовищі могли бути колишніми чорноморськими козаками та їхніми нащадками, які пішли працювати до каменоломень Одеси. Вказуеться, що на кладовищі поховані в тому числі й родичі тих каменярів, які здобували каміння для спорудження сучасного символу Одеси - Потьомкінських сходів.

Ключові слова: козацькі кладовища, некрополь, Одеса, Кульяник.

Куяльницьке (Сотниківське) кладовище, що розташоване в межах міста Одеси на схимі Шкодової гори неподалік Хаджибеївського миману, протягом кількох останніх десятиліть привертає жваву увагу дослідників та аматорів вивчення минулого. Назва одеського передмістя Куяльник 
(Малий Куяльник) поблизу якого розташоване кладовище, вочевидь, пов'язана з назвою, яку мав Хаджибеївський миман у XVIII ст. - Великий Куяльник. Це зумовлює і назву вказаного кладовища. Народна ж назва "Сотниківський" вочевидь виникла на честь хреста заокругленої форми в центральній частині кладовища, надпис на якому містить слова: "...здесь спочиває младєніцъ /антифимъ синъ марка сотни /ченка августа 21 / 1824 года" [14, с. 2]. Надгробки (переважно хрести) Куяльницького кладовища є унікальними пам'ятками історії та народної матеріальної культури, що вражають різноманітністю форм. Каменярі, які мешкали у одеському передмісті Куяльник, у виготовлені намогильних хрестів поєднували збереження давніх запорозьких традицій з їхнім розвитком, використовуючи для того м'яке та пластичне місцеве каміння - вапняк. Це зумовлює необхідність збереження та наукового вивчення вказаного кладовища.

Аналіз публікацій присвячених Куяльницькому та розташованим неподалік від нього Усатовому та Нерубайському кладовищам вже було

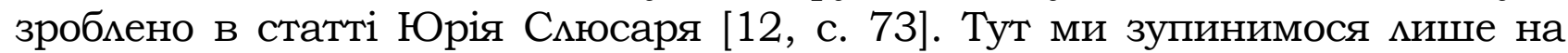
одному аспекті вивчення кладовища, базуючись на двох наукових виданнях, а саме: на публікації відомого одеського краєзнавця, дослідника некрополів Одещини Р. Шувалова (1911 - 2002 рр.), що вийшла друком 1992 р. та публікації археолога, дослідника палеоліту I. Сапожникова 1999 р. (обидві публікації, попри їхню наукову цінність, невеликі за обсягом, тому у подальшому ми називатимемо їх брошурами) [9].

Вищезгаданий аспект стосується датування найстарішого надгробного хреста 3 надписом, що розташований на кладовищі. Р. Шувалов у своїй брошурі датував цей хрест 1791 р., наводячи і надпис на ньому: «здсъпо /грєбнъ / рабъ / божи / ін хс/ мАдєнцъ иоанъ/ року божиа / 1791" [14, с. 30]. I. Сапожников наводячи цей же надпис 3 посиланням на I. Шувалова подав іншу дату - не 1791, а 1771 рік. Пояснюючи своє датування І. Сапожников, стверджує: «Відзначимо, що Р. Шувалов датує його [хрест] $1791 \mathrm{p}$. Таке різночитання пояснюється тим, що третю цифру дати пошкоджено. Складається враження, що іiі очищали від вапна за допомогою гострого ножа. Автор кілька разів детально досліджував дату на хресті й прийшов до висновку, що третя цифра може бути 1 або 7 , але ніяк не 9" [9, с. 61].

Стосовно ситуації, що склалася навколо датування найдавнішого підписаного хреста кладовища та вищенаведеної цитати I. Сапожникова нам би хотілося зробити кілька зауважень. По-перше, Р. Шувалов нічого не писав про пошкодження вищезгаданого хреста. I в своїй брошурі, і в замальовці, що зберігається в його особистому архівному фонді $[3$, арк. 32], він чітко датує хрест 1791 р. Це пояснюється тим, що хрест було пошкоджено саме у проміжок часу між виходом брошури Р. Шувалова (1992 р.) та брошури I. Сапожникова (1999 р.). Автор цих рядків може підтвердити, що ще в середині 1990-х рр. на хресті абсолютно ясно читалася дата 1791 рік.

По-друге, на нашу думку (виходячи 3 власних спостережень за станом вказаного надгробку протягом низки років), причиною пошкод- 
ження хреста було не невдале очищення від вапна ножем, а намагання штучно "збільшити його вік" (користуючись м'якістю матеріалу з якого хрест зроблено), переробивши цифру 9 на 7. Зазначений акт вандалізму, а також подальші спроби невідомих осіб "навести" вже виправлену на хресті дату, призвели до того, що, на сьогодні, на хресті автентичним виглядає мише написання першої цифри дати поховання, а останні дві цифри взагалі неможливо розібрати.

По-третє, датування надгробку 1771 р. ніяк не вписується в поширену в мітературі думку про заснування посемень під Хаджибеєм (Куяльника, Нерубайського та Усатового) колишніми запорозькими козаками після зруйнування Січи 1775 р. Звичайно українське населення у межиріччі Південного Бугу та Дністра (так званій "Ханській Україні») з'явияося набагато раніше, але прізвища (прізвиська) багатьох мешканців передмістя Куямьник XIX ст. свідчать про їх запорозьке, а не просто українське, походження (на що звертав увагу Р. Шувалов [14, с. 10]).

Нарешті, по-четверте, досить важко пояснити, яким чином могцо 3'явитися дитяче поховання в цій місцевості під час розгортання в ній бойових дій російсько-турецької війни 1768 - 1774 рр. Адже вже у вересні-жовтні 1769 р. околиці Хаджибея були спустошені загоном

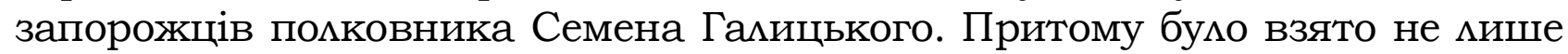
чималу здобич (36 тисяч коней, тисячу гомів рогатої худоби, чотири тисячі овець та 180 верблюдів [11, с. 463-464; 1, с. 28]), але й захоплено у полон турок і татар, в тому числі дітей, які пізніше були "презентовані" членам царської родини та вищім сановникам імперії (серед них, зокрема, був "хлопчик Кутай аулу Буркут", хрещений наслідником престолу Павцом, який за царювання останнього став його фаворитом Іваном Кутайсовим [7, с. 113]). У 1770 р. терени навкомо Хаджибея буми піддані ще більшому спустошенню запорожцями кошового отамана Петра Калнишевського та іншими військами віддіку генерал-майора Олександра Прозоровського (калмиками, донськими козаками та ін.). Під час цього походу в запеклому бою було здобуто усе місто Хаджибей окрім фортеці. Як зазначалося в журналі російської армії, всі вороги, які тоді у фортеці Хаджибея "запертися не встигли, ...зовсім були переможені та знищені, а мирні мешканці в полон взяті й до поселення в Новоросійську губернію відправлені" [5, с. 179-180]. Тоді в краї (околицях Хаджиебея та Аджидере) було захоплено та примусово виселено до російських володінь "до 5000 тисяч волохів обох статей, 222 розкольника, 24 єврея, 153 чоловік циган" [6, с. 360]. Воєнні дії в районі Хаджибею та прилеглих теренах велися 3 мипня до початку вересня 1770 р. Запорожці здійснювали походи під Хаджибей і у 1771 р. [11, с. 496], хоча, за твердженням сучасного історика Г. Шпитальова: "На 1771 р. ОчаковоХаджибейський район, спустошений у попередню кампанію деташементом О.Прозоровського, дия російського командування значення втратив" [13, с. 171]. Повторимо, що за таких умов неясно, як могло у 1771 р. тут з'явитися поховання "младенца Иоанна". I. Сапожников жодних пояснень щодо цього не надає. 
Виходячи 3 вище наведених аргументів, вважаємо набагато ймовірнішим датування найдавнішого збереженого на сьогодні підписаного надгробку Куяльницького кладовища подане Р. Шуваловим 1791 рік. Це підтверджується і тим, що хрест "младенца Иоанна" оточений масивом інших надгробків, в тому числі з надписами XIX ст., що опосередковано свідчить про безперервність поховань на кладовищі в кінці XVIII - XIX ст. В разі датування хреста 1771 р., це було б неможливо через події не кише згаданої війни 1768 - 1774 рр., але й російськотурецької війни 1787 - 1791 рр. В такому разі також не ясно, чому в міжвоєнний період запорожці, які насправді втекли до околиць Хаджибея після зруйнування Січи 1775 р., не були виселені звідти за Дунай, як це було передбачено артикулом $\mathrm{V}$ пунктом 3 російсько-турецької Айналикавакської конвенції 1779 р. [4, с. 363]. Датування найстарішого підписаного надгробку кладовища запропоноване Р. Шуваловим (1791р.) може подекуди змінити погляд на початки історії одеського передмістя Куяльник (Малий Куяльник). Вони цілком можуть бути пов'язаними, не 3 1775 р., а з наданням "великим гетьманом" Григорієм Потьомкіним 1 березня 1790 р. чорноморським козакам (колишнім запорожцям) земель між Південним Бугом (Богом) - на сході, Дністром - на заході, дорогою Бендери - Соколи (Вознесенськ) - на півночі і циманами та морем - на півдні. Як писав пізніше у своєму вірші Антон Головатий:

"...Да й дав же гетьман [землю] од Дністра до Богу,

Границя по бендерську дорогу,

Дністровський і Дніпровський обидва Аимани,

В них добувати рибу, справляти каптани...." [8, с. 207]

До наданих тоді чорноморцям земель входив і Хаджибей з околицями (в опублікованих документах навіть згаданий чорноморський "полковник Аджибея", який у вересні 1790 р. доповідав про "мешканців слобод, які підлягають Чорноморському війську" [10, с. 200]). Як відомо, значна частина чорноморців не забажала переселятися 1792 р. на землі по р. Кубань і залишилися в цьому краї, взявши участь у розбудові Одеси.

Відповідь на запитання про час заснування передмістя Куяльник можливо можна буде знайти, порівнюючи прізвища його мешканців у XVIII - XIX ст. зі списками Запорозького та Чорноморського козацьких військ. Необхідними є також дослідження ролі каменярів Куяльника та інших одеських передмість у розбудові Одеси XIX ст. Наприклад, нам вдалося встановити, що прізвища Шмигора присутне на хресті Куяльницького кладовища датованого 1840 р. [14, с. 27], співпадає 3 прізвищами власників каменярень Куяльника (Малого Куяльника), які 1837 р. видобували каміння для спорудження сучасного символу Одеси Бульварних (Потьомкінських) сходів [2, арк. 115]. Вважаємо, що подальші дослідження історії Куяльницького (Сотниківського) кладовища Одеси принесуть ще чимало наукових відкриттів. 


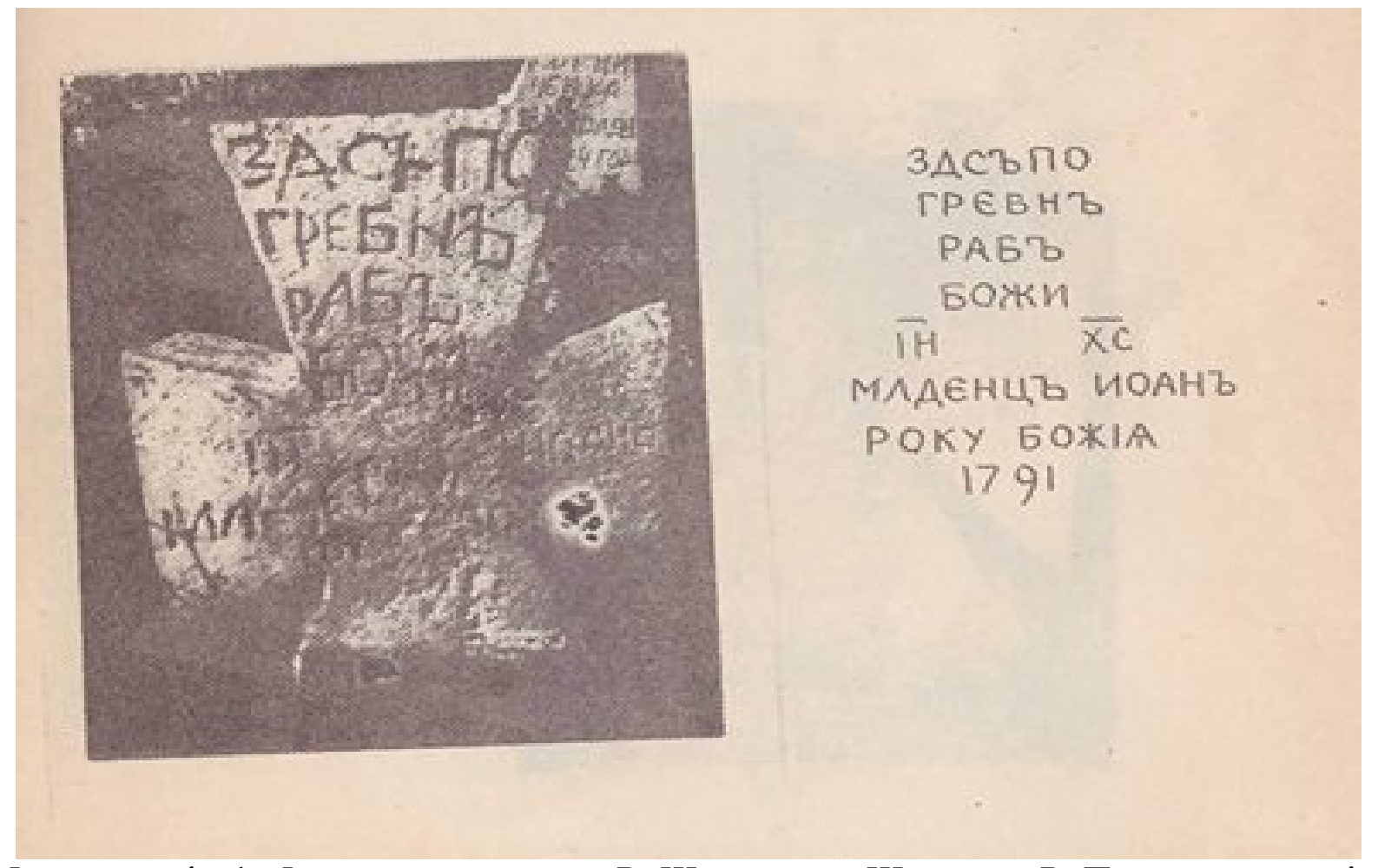

Ілюстраиія 1. Фрагмент з книги Р. Шувалова: Шувалов Р. Про шо розповів некрополь (Куяльнииьке козаиьке кладовище міста Одеси). Київ, 1992. - C. 30.

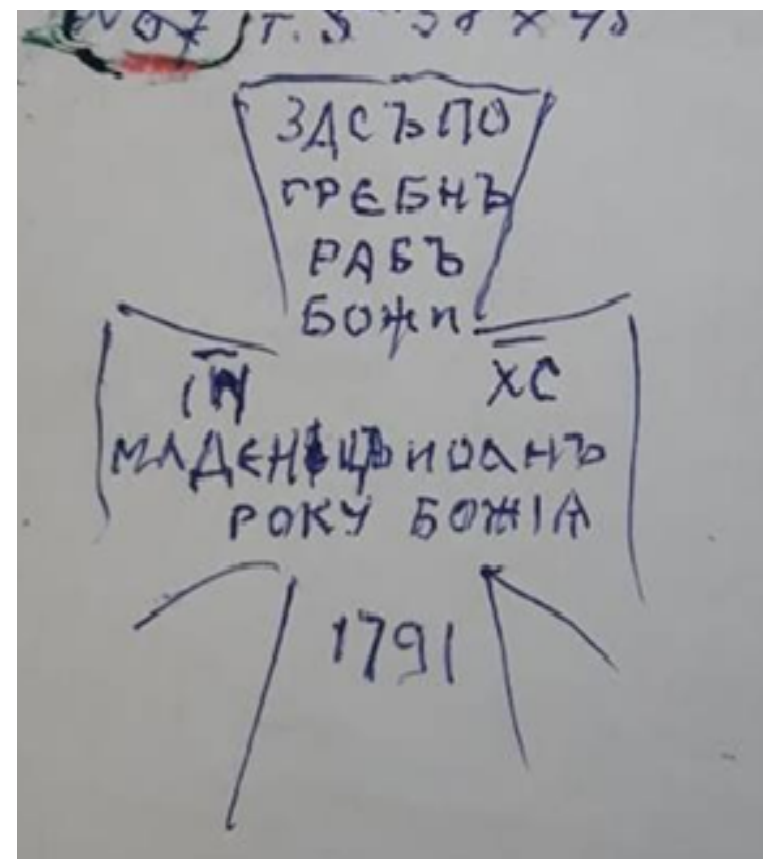

Ілюстраиія 2. Фрагмент із замальовок надгробків Куяльнииького (Сотніківського) кладовиша Р. Шувалова: Держархів Одеської області. Ф. P-8187. - On. 1. - Cnp. 35. - Аpк. 32.

\section{Джерема та мітература:}

1. Гончарук Т.Г. Запорозьке козацтво та Хаджибей (Одеса). Середина XVI ст. - 1775 рік // Одеса козацька. Наукові нариси. Видання друге, змінене та доповнене. - Одеса, 2008. - 239 с.

2. Держархів Одеської області. - Ф. 59. - Оп. 2. - Спр. 459. - Ч. IV. 
3. Держархів Одеської області. - Ф. Р-8187. - Оп. 1. - Спр. 35.

4. Дружинина Е.И. Кючук-Кайнарджийский мир 1774 года (его подготовка и подписание). - М.1955. - 384 с.

5. Журнал военных действий армий Ея Императорского Величества 1770 года. - СПб., Бг. - 351 с.

6. Журнал генерал-фельдмаршала князя А.А. Прозоровского. - СПб., Бг. - 784 с. 7. Маркевич А. Граф Иван Павцович Кутайсов // Записки Одесского общества истории и древностей. - Т.23. - С. 113-132.

8. Мороз Д. Как справляли черноморцы свое новоселье на Тамани и какие быми по сему случаю речи и песни // Киевская старина. - 1883. - Т. V. - №1. - C. 207.

9. Сапожников И. В. Каменные кресты предместий Одессы (конец XVIII XIX вв.) - ИАьичевск, 1999. - 98 с.

10. Сборник исторических материалов по истории Кубанского казачьего войска. - СПб., 1896.- Т.3. - С. 200.

11. Скальковський А. О. Історія Нової Січі або останнього Коша Запорозького. - Дніпропетровськ, 1994. - 678 с.

12. САюсар Ю. Історичні цвинтарі Шкодової гори як об’єкт уваги науковців і краєзнавців-аматорів в останнє десятиріччя XX ст. та основа подальшого розвитку історичного краєзнавства та пам'яткоохоронної справи на Одещині // Вісник Одеського історико-краєзнавчого музею. Аипень 2005 р. - Одеса, 2005. - С. 73-78.

13. Шпитальов Г. Г. Військова служба запорозького козацтва в Російськотурецьких війнах 1768 - 1774 років. - Запоріжжя, 2004. - 240 с.

14. Шувалов Р. Про що розповів некрополь (Куяльницьке козацьке кладовище міста Одеси). - Київ, 1992. - 89 с.

\section{References:}

1. Honcharuk T.H. Zaporoz'ke kozatstvo ta Khadzhybey (Odesa). Seredyna XVI st. 1775 rik, Odesa kozats'ka. Naukovi narysy. Vydannya druhe, zminene ta dopovnene. Odesa, 2008. 239 c. [in Ukranian].

2. Derzharkhiv Odes'koyi oblasti. F. 59. Op. 2. Spr. 459. Ch. IV.

3. Derzharkhiv Odes'koyi oblasti. F. R-8187. Op. 1. Spr. 35.

4. Druzhinina E. I. Kyuchuk-Kaynardzhiyskiy mir 1774 goda (ego podgotovka i podpisaniye). M., 1955. 384 c.

5. ZHurnal voyennykh deystviy armiy Eya Imperatorskogo Velichestva 1770 goda. $\mathrm{SPb} ., \mathrm{Bg} .351 \mathrm{~s}$.

6. ZHurnal general-fel'dmarshala knyazya A. A. Prozorovskogo. SPb., Bg. 784 s.

7. Markevich A. Graf Ivan Pavlovich Kutaysov, Zapiski Odesskogo obshchestva istorii i drevnostey. T. 23. S. 113-132.

8. Moroz D. Kak spravlyali chernomortsy svoye novosel'ye na Tamani i kakiye byli po semu sluchayu rechi i pesni, Kiyevskaya starina. 1883. T. V. №1. C. 207.

9. Sapozhnikov I. V. Kamennyye kresty predmestiy Odessy (konets XVIII XIX vv.) Il'ichevsk, 1999. 98 c.

10. Sbornik istoricheskikh materialov po istorii Kubanskogo kazach'yego voyska. SPb., 1896. T. 3. S. 200.

11. Skal'kovs'kyy A. O. Istoriya Novoyi Sichi abo ostann'oho Kosha Zaporoz'koho. Dnipropetrovs'k, 1994. 678 s. [in Ukranian].

12. Slyusar Yu. Istorychni tsvyntari Shkodovoyi hory yak ob"yekt uvahy naukovtsiv i krayeznavtsiv-amatoriv v ostannye desyatyrichchya XX st. ta osnova podal'shoho rozvytku istorychnoho krayeznavstva ta pam"yatkookhoronnoyi 
spravy na Odeshchyni, Visnyk Odes'koho istoryko-krayeznavchoho muzeyu. Lypen' 2005 r. Odesa, 2005. S. 73-78.

13. Shpytal'ov H. H. Viys'kova sluzhba zaporoz'koho kozatstva v Rosiys'koturets'kykh viynakh 1768 - 1774 rokiv. Zaporizhzhya, 2004. 240 s. [in Ukranian]. 14. Shuvalov R. Pro shcho rozpoviv nekropol' (Kuyal'nyts'ke kozats'ke kladovyshche mista Odesy). Kyyiv, 1992. 89 s. [in Ukranian].

Тарас Гончарук

К истории изучения Куяльницкого (Сотниковского) кладбища в Одессе

Вниманию читателей предложено анализ информаиии и историографию изучения могильника Куяльниикого предместья, расположенного в Одессе, в котором находятся надгробия (кресты), аналогичные надгробиям запорожского казачества. Кроме того, исследование доказывает правильную датировку самой старой подписанной надгробной плиты на кладбише (1791 г.), которая была впервые задокументирована ученъм Романом Шуваловьм. Автор публикаиии предложил версию, что люди, похороненные на кладбише, могли быть бывшими черноморскими казаками и их потомками, которые отправились на работу в карьер Одессы. Ученьй отметил, что на кладбище были также похоронены родственники тех каменшиков, которые добывали камни для строительства современного символа Одессы - Потемкинской лестнииь.

ключевъе слова: казаикие кладбиша, некрополь, Одесса, Кульяник.

Отримано 3.12.2018 p. 